\title{
Potential ecological risk assessment of a stream in Shamva, Zimbabwe
}

\author{
Artwell Kanda*, France Ncube, Rumbidzai Takura \\ Bindura University of Science Education, BUSE, P. Bag 1020, +263 Bindura, Zimbabwe
}

Received: 5 October 2016

Accepted: 22 January 2017

Published online: 4 March 2017

\begin{abstract}
Water bodies are the final sinks of all pollution with more than $90 \%$ of contaminants found in suspended particulates and bottom sediments. Only less than $10 \%$ is retained in the water column yet it attracts and receives great research attention. The pollution status and the potential ecological risk of three pools of water along a stream due to heavy metal enrichment from a nearby active gold mining tailings dam were assessed. The upstreamdownstream and sedimentological approaches to ecosystem health assessment were used. Potential uses of pool water were also evaluated based on measured water quality parameters. Heavy metals in water and sediment were determined using Flame Atomic Absorption Spectrometry. Results revealed that salinisation, acidification and heavy metals were exported from a mining tailings dam to the stream. The degree of contamination of pool water by heavy metals dictated water uses. Heavy metal concentrations imposed water use restrictions for aquatic life in a pool which directly received discharge from the mine tailings dam. The average heavy metal concentrations in sediments were lower than the standard shale values. Sediment quality guidelines and pollution indices showed that the stream was not polluted with heavy metals, thus posed no potential ecological risk. Continuous monitoring of tailings discharge and wash off is important to safeguard aquatic ecosystem and public health.
\end{abstract}

Keywords: metal, pollution, sediment, tailings, risk

\section{Introduction}

Fine particulates of mining tailings are subject to environmental manipulation thus potentially release heavy metals into the aquatic system (Ciszweski et al. 2013) of which more than $90 \%$ are found in sediments and suspended materials (Calmano and Forstner 1993). Sediments play an important role in heavy metal cycling in aquatic environments (Ongley 1996). Some heavy metals are essential for plant and animal nutrition but they may be toxic at elevated concentrations (Forstenr and Wittmann 1981). Public health effects of heavy metals are well documented (Jaishankar et al. 2014; WHO 2011b) are well documented. Sediment-associated heavy metals are not expected to present a direct ecological risk provided they remain immobilised by encapsulation (Singh et al. 2005). However, they are subject to remobilisation into the water column by in-stream hydrodynamic processes and external factors

\footnotetext{
* Corresponding author: Artwell Kanda
}

e-mail: alzkanda@gmail.com 
Artwell Kanda et al.

(Eggleton and Thomas 2004). Once remobilised and conditions permitting, heavy metals may become bioavailable to aquatic organisms and get exported to the terrestrial environment via the food chain. The analysis of heavy metals in bed sediments of water bodies near human settlements becomes crucial, not only to establishing anthropogenic impacts on the aquatic ecosystem, but also to investigating water use options (Yi et al. 2011).

Municipal and industrial sewage discharges into watercourses and reservoirs have dominated river water quality research in Zimbabwe, especially in urban settlements. Most of the work seems to have focused on the pollution status of the water column (e.g. Jonnalagadda and Mhere 2001; Nhapi and Tirivarombo 2004; Nyamadzawo et al. 2007; Kibena et al., 2014). None of these studies seem to have linked heavy metal content of bed sediments to the potential health of aquatic ecosystems. The sedimentology approach is an alternative way of assessing the health of aquatic ecosystems to laboratory assays which can be expensive, and to measuring ecosystem structure and abundances which can be time-consuming (Maher et al. 1999).

Sediment quality with respect to heavy metals, has been used to evaluate the pollution status and ecological health of watercourses and reservoirs using pollution indices (Mohiuddin et al. 2011; Majnoni et al. 2015), sediment quality guidelines (SQGs) (Maher et al. 1999; Soliman et al. 2015) and the ecological risk index (RI) (Liu et al. 2005). Four indices were used in this study (CF, PLI, Igeo and RI) to assess the pollution status of three pools of water along a stream that passes near $(<100 \mathrm{~m})$ an active gold mining tailings dam. Heavy metal concentrations in sediments were compared to SQGs. The up-and downstream approach was used to establish the contribution of the tailings dam drainage to the concentration of heavy metals in water and sediment. We hypothesised that heavy metal concentrations in pools of water were above threshold limits for various uses. Continuous monitoring of heavy metals in water, soil and vegetation near mining tailings dams becomes important since some heavy metals are toxic, persistent and bioaccumulate, thus posing environmental and public health risks.

\section{Materials and Methods}

\subsection{Description of the study area}

The study was done in Shamva district $\left(17^{\circ} 19 \mathrm{~S} 31^{\circ} 3 \mathrm{E}\right)$ of Zimbabwe within the greenstone belt of the Shamvaian sediments whose ore bodies mineralisation according to Shoko and Tobani (2001) consists predominantly of pyrite ( $>90 \%)$ with minor sphalerite, galena, chalcopyrite, pyrrhotite and arsenopyrite. The annual rainfall range is $750-1000 \mathrm{~mm}$ and the mean annual temperature varies from $19-30^{\circ} \mathrm{C}$. Mushambanyama Stream feeds into Magobo dam. Under normal rainfall events the stream is perennial. The poorly vegetated and unlined active tailings dam drains into the stream.

\subsection{Sampling and sample analysis}

Two pools of water; L2 and L3 were considered 600 and 1200m downstream respectively and L1, 100m upstream (Fig. 1). At each sampling site (pool) four grab water samples were randomly collected from just below the surface $(10 \mathrm{~cm})$ in acid-cleaned polyethylene bottles $(100 \mathrm{ml})$. Water samples were filtered through $0.45 \mu \mathrm{m}$ pore diameter membrane filters (Chapman and Kimstach 1996) and separated into two subsamples; acidified with $2 \mathrm{ml}$ dil. $\mathrm{HNO}_{3}\left(1: 1 ; \mathrm{H}_{2} \mathrm{O}\right)$ for dissolved heavy metal analysis and unacidified for organic matter (OM) determination, and preserved on ice (Yi et al. 2011). Thirty-six water samples were collected from the three sites in September, October and November, 2015. Water $\mathrm{pH}$ and EC were determined on site using a calibrated multi-parameter tester 35 (Eutech Instruments, USA). Water samples were preconcentrated before analysis following procedures described by Divrikli et al. (2007). An acidified water sample (300ml) was put in a beaker and the $\mathrm{pH}$ was adjusted to 9 using $0.1 \mathrm{MNaOH}$. The sample was passed through a cellulose nitrate membrane filter 
Artwell Kanda et al.

$(0.45 \mu \mathrm{m}$ pore size and $47 \mathrm{~mm}$ diameter) under suction. The membrane filter and collected analytes were dissolved in conc. $\mathrm{HNO}_{3}(0.5 \mathrm{ml})$ at $80^{\circ} \mathrm{C}$. The final solution was diluted to $10 \mathrm{ml}$ with deionised water and analysed for selected heavy metals using Flame Atomic Absorption Spectrometry (FAAS).

The sampling and pre-treatment of sediment samples were done following procedures described by Singh et al. (2010). Three grab sediment cores $(0-10 \mathrm{~cm})$ were sampled from each pool where water was sampled using a polypropylene corer $(1 \mathrm{~m}$ long with extensions, $10 \mathrm{~cm}$ internal diameter) into polyethylene bags. Samples were air dried and screened ( $63 \mu \mathrm{m}$ nylon sieve). The $\mathrm{pH}$ of sediment solution was determined by agitation and equilibration (10g sediment) with double distilled water $(50 \mathrm{ml})$ by stirring at regular intervals $(1 \mathrm{~h})$ then measured with a tribuffer-calibrated $(\mathrm{pH} 4,7$ and 10) $\mathrm{pH}$ meter (AD $1020 \mathrm{pH} / \mathrm{mV} / \mathrm{ISE}$ and temperature meter). The OM content was determined by wet oxidation-redox titration using acidified dichromate solution. Dry sieved sediments (305g) were added to a $500 \mathrm{ml}$ conical flask. Concentrated $\mathrm{H}_{2} \mathrm{SO}_{4}(20 \mathrm{ml})$ and $1 N \mathrm{~K}_{2} \mathrm{Cr}_{2} \mathrm{O}_{7}(10 \mathrm{ml})$ were added and the mixture was allowed to react for $30 \mathrm{~min}$. After diluting to $200 \mathrm{ml}$, the sample was titrated with $0.4 \mathrm{~N}$ ferrous $\left(\mathrm{NH}_{4}\right)_{2} \mathrm{SO}_{4}$ using a ferrion indicator to determine OM content. Total heavy metals were extracted from a split dry sample $(1 \mathrm{~g})$ of sediment in open acid-mixture (conc. $\mathrm{HCl}: \mathrm{HNO}_{3}: \mathrm{HCLO}_{4} ; 3: 1: 1,20 \mathrm{ml}$ $\mathrm{v} / \mathrm{v}$ ) digestion over a hot plate. Cooled digests were filtered into a $50 \mathrm{ml}$ volumetric flask using deionised water for washings and made to the mark. No rainfall events occurred during the study.

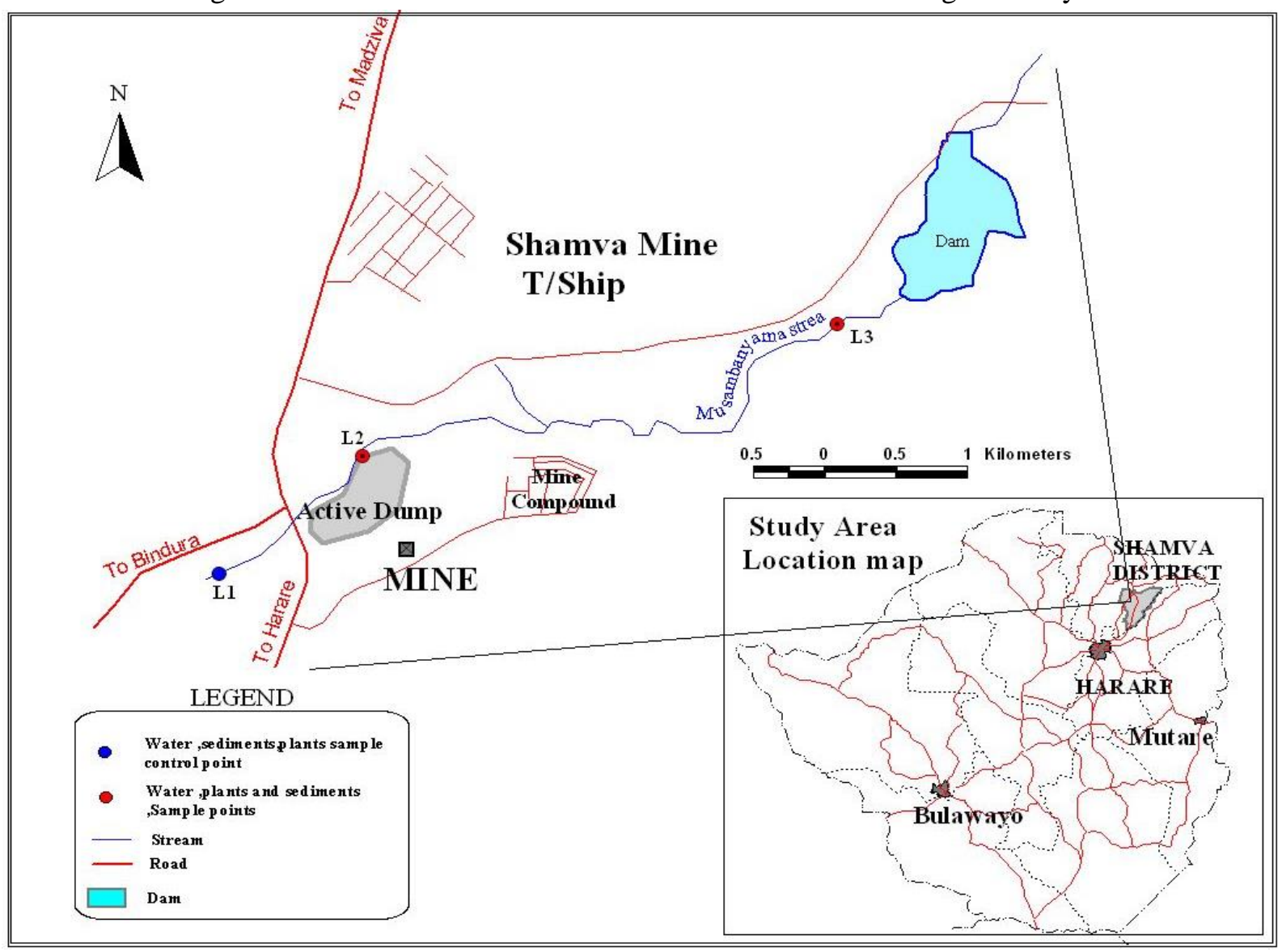

Fig. 1The study area showing the location of pools of water along the stream under study.

\subsection{Data analysis}

Pollution indices and the potential ecological risk were determined using equations 1-4 and interpretation guidelines (Tab. 1).

$$
C f=\frac{c_{s}^{i}}{c_{n}^{i}}
$$


$C_{s}^{i}$ and $C_{n}^{i}$ represent the content of heavy metal (i) in the test sample (s) and the background sample (n) respectively. Background values that were used were the geochemical average shale: 6.6, 90, 45, 46700, 850 and 20 for As, $\mathrm{Cr}, \mathrm{Cu}, \mathrm{Fe}, \mathrm{Mn}$ and $\mathrm{Pb}$ respectively (Turekain and Wedpohl 1961).

$$
P L I=\left(C f 1{ }^{*} C f 2{ }^{*} C f 3{ }^{*} C f n\right)^{1 / n}
$$

Eq. 2

Cf is the contamination factor for heavy metal 1,2,3 measured in sediment; $n$ is the number of heavy metals whose concentration was measured.

$$
I-g e o=\log _{2}(C m \mid 1.5 * B m) \quad E q .3
$$

$C_{m}$ is measured concentration of trace element ' $\mathrm{m}$ ' in sediment and $B m$ represents the geochemical background value trace element ' $m$ ' in average shale.

$$
R I=\sum E_{r}^{i}=\sum T_{r}^{i} * C_{f}^{i}=\sum T_{r}^{i} * \frac{C_{s}^{i}}{C_{n}^{i}}
$$

$C_{s}^{i}$ and $C_{n}^{i}$ represent the content of heavy metal (i) in the test sample (s) and the background sample (n) respectively. $T_{r}{ }_{r}$ represents the toxic response factor for heavy metal (i) with values $10,2,5$ and $5 \mathrm{mg} / \mathrm{kg}$ for $\mathrm{As}, \mathrm{Cr}, \mathrm{Cu}$ and $\mathrm{Pb}$ respectively (Forstner 1989). $E_{r}^{i}$ represents the potential ecological risk index of each heavy metal and $R I$ is the sum of the potential risk of all individual heavy metals studied.

\subsection{Quality control procedures}

Polythene water sampling bottles were pre-treated by soaking in dil. $\mathrm{HNO}_{3}$ overnight and repeatedly rinsed with double deionised water. Samples were replicated three times. Samples for trace element analysis were preserved by acidifying with conc. $\mathrm{HNO}_{3}$ to $\mathrm{pH}<2$. Sample blanks were used in between analyses (every batch of ten) and sample standards were analysed again after the analysis of a ten sample batch. Certified reference material CRM) (channel sediment BCR 320R: 0083, European Commission Community Bureau of Reference) was used to check the precision of the analytical procedure. Three replicates of the CRM were digested and analysed for total heavy metals using the same procedures. Water $\mathrm{pH}$ and $\mathrm{EC}$ were determined in situ.

\subsection{Statistical analyses}

Normalised data were subjected to ANOVA to compare means of variables from different sampling sites. The Tukey B post-hoc procedure was used to separate measured means at $\mathrm{p}<0.05$ using the Paleontological Statistical Software Package (Hammer et al. 2001). Estimated water quality parameters were compared to international guidelines for various water uses using a one sample $t$-test: (i) drinking water quality guidelines (WHO 2011a), (ii) Water quality requirements for agriculture (FAO 1985) and (iii) fresh water quality requirements for aquatic life of biota (CCME 2008). Measured sediment quality data were compared with SQGs (CCME 2001) using a one sample $t$-test. A Pearson correlation test was used to determine the strength of association between measured parameters of water, sediment and between water and sediment.

\section{Results}

There were no background levels of heavy metals in sediments for this study therefore the geochemical composition of shale was used. Reagent blanks showed no contamination during the analytical procedure and standard solutions had negligible deviations. Heavy metal recoveries of the 
certified reference material were $93.34 \pm 0.02(\mathrm{~Pb})$ and $103.76 \pm 0.03 \%(\mathrm{Cu})$. Both water and sediment quality data showed no significant temporal variation over three months $(\mathrm{p}>0.05)$.

\subsection{Heavy metal concentration in water and potential water uses}

Table 2 shows the variation of physicochemical parameters of water samples taken from three pools of water along Mushambanyama Stream. Results show that $\mathrm{As}, \mathrm{Cr}, \mathrm{Cu}$ and $\mathrm{Pb}$ were not detected upstream (L1) and further downstream (L3). The concentrations of Fe and Mn at L1 and L3 showed the trend $\mathrm{L} 1=\mathrm{L} 3<\mathrm{L} 2$ while $\mathrm{EC}$ and $\mathrm{pH}$ recorded at the three pools showed: $\mathrm{L} 1<\mathrm{L} 2>\mathrm{L} 3$ and $\mathrm{L} 2<\mathrm{L} 1<\mathrm{L} 3$ respectively. The values of measured parameters from the three pools of water L1, L2 and L3 were within the water quality requirements for the four different uses which are potable, irrigation, fresh water life and watering livestock. However, EC at L2 did not meet the water quality requirement for irrigation. At L2, Cr and Fe did not meet the water quality requirement for fresh water life.

\subsection{Characteristics of sediment and sediment quality guidelines}

Table 3 shows the variation of physicochemical parameters of sediment samples taken from three pools of water along Mushambanyama Stream. Results show that the concentrations of As, $\mathrm{Cr}$ and $\mathrm{Pb}$ were below the detectable limit (ND) in sediments from $\mathrm{L} 1$. Arsenic was also below the limit of detection at L3. The concentrations of heavy metals in sediments from the three pools of water were below $(\mathrm{p}<0.05)$ the lower threshold values for sediment quality (TEL). Sediments from L2 contained the highest content of OM and the highest EC ( $<<0.05)$. They also showed the lowest $\mathrm{pH}$ which was acidic. The variation of sediment parameters across sampling points showed a trend: $\mathrm{L} 1<\mathrm{L} 3<\mathrm{L} 2$, except for $\mathrm{As}$ and $\mathrm{Cu}$.

\subsection{Sediment quality using indices}

Table 4 shows the computed values for evaluating sediment quality and the potential ecological risk of three pools of water due to heavy metals up-and-downstream of Mushambanyama Stream relative to a nearby active gold tailings dam. Results reveal that the $\mathrm{CFs}$ for $\mathrm{As}, \mathrm{Cr}, \mathrm{Cu}, \mathrm{Fe}, \mathrm{Mn}$ and $\mathrm{Pb}$ were all below unity. The PLI was also below unity. Computed I-geo values put all sediments in class 0 . The $\mathrm{E}_{\mathrm{i}}^{\mathrm{r}}$ and RI values (Tab. 4) put sediments from all the three sites in the $<40$ and $<150$ index ranges (Tab. 1) respectively.

Table 6 shows the strength of associations between water-water, water-sediment and sediment-sediment parameters using Pearson correlation coefficients considered significant at $\mathrm{p}<0.05, \mathrm{p}<0.01$ and $\mathrm{p}<0.001$. All water and sediment quality parameters showed significant ( $\mathrm{p}<0.001)$ and positive correlation with $\mathrm{EC}_{\mathrm{w}}$ except with $\mathrm{Cr}_{\mathrm{w}}(\mathrm{p}<0.05), \mathrm{pH}$ and $\mathrm{pH}_{\mathrm{w}}$ (negative), $\mathrm{As}$, and $\mathrm{Cu}_{\mathrm{w}}$ (not significant, $\mathrm{p}>0.05$ ). On the contrary, $\mathrm{pH}_{\mathrm{w}}$ had significant $(\mathrm{p}<0.001)$ but negative correlation with the same parameters except with $\mathrm{pH}$ (positive) and with $\mathrm{As}, \mathrm{Pb}_{\mathrm{w}}, \mathrm{AS}_{\mathrm{w}}$ and $\mathrm{Cr}_{\mathrm{w}}$ (Not significant, $\mathrm{p}>0.05$ ). The following pairs of parameters for water and sediment showed significant $(\mathrm{p}<0.001)$ positive associations: $\mathrm{pH} / \mathrm{pH}_{\mathrm{w}}, \mathrm{EC} / \mathrm{EC}_{\mathrm{w}}, \mathrm{Cu} / \mathrm{Cu}_{\mathrm{w}}, \mathrm{Fe} / \mathrm{Fe}_{\mathrm{w}}$ and $\mathrm{Mn} / \mathrm{Mn}_{\mathrm{w}}$. However, $\mathrm{As} / \mathrm{As}_{\mathrm{w}}, \mathrm{Cr} / \mathrm{Cr}_{\mathrm{w}}$ and $\mathrm{Pb} / \mathrm{Pb}_{\mathrm{w}}$ pairs showed weak negative correlations which were not significant ( $p>0.05)$. These heavy metals were not detected in water at the reference point upstream (L1) and further downstream (L3). Organic matter and $\mathrm{pH}$ which potentially influence the complexation or mineralisation of heavy metals in sediments were negatively and significantly $(\mathrm{p}<0.001)$ correlated. 
Artwell Kanda et al.

Tab. 1 Calculation and interpretation of pollution indices and the potential ecological risk index of heavy metal-bound sediments from three pools of water in Mushayanyama Stream.

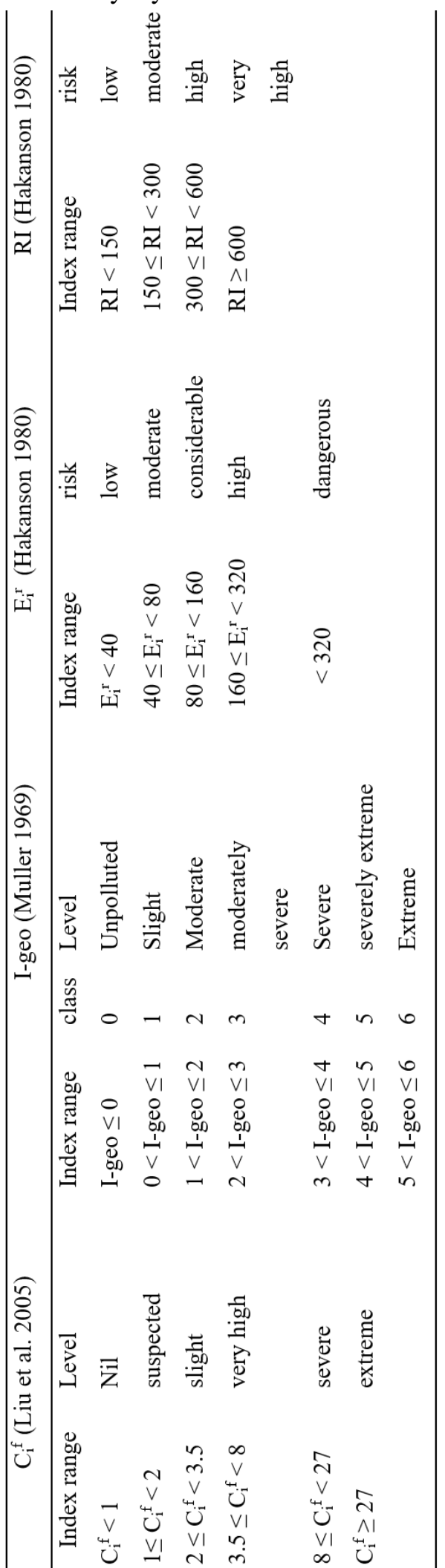

Tab. 4 Mean values $(n=9)$ of indices used to assess sediment quality of pools of water along Mushambanyama Stream from SeptemberNovember, 2015.

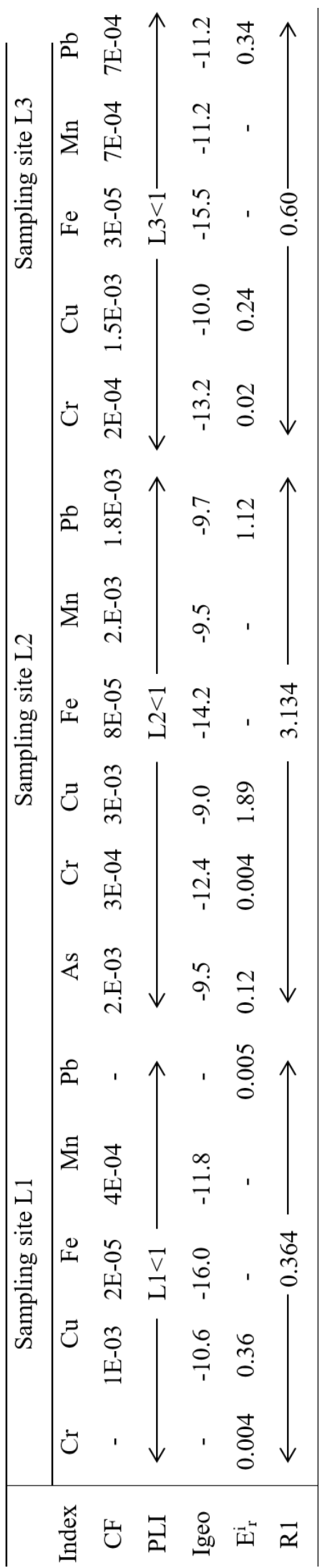


Artwell Kanda et al.

Tab. 2 Physicochemical parameters of water sampled from three pools along Mushayanyama Stream from September-November, 2015. Values are reported as means of replicate $(n=9)$ measurements $(\mathrm{mean} \pm \mathrm{SE}$ ). Units are $\mathrm{mg} / \mathrm{l}$ for heavy metals unless specified.

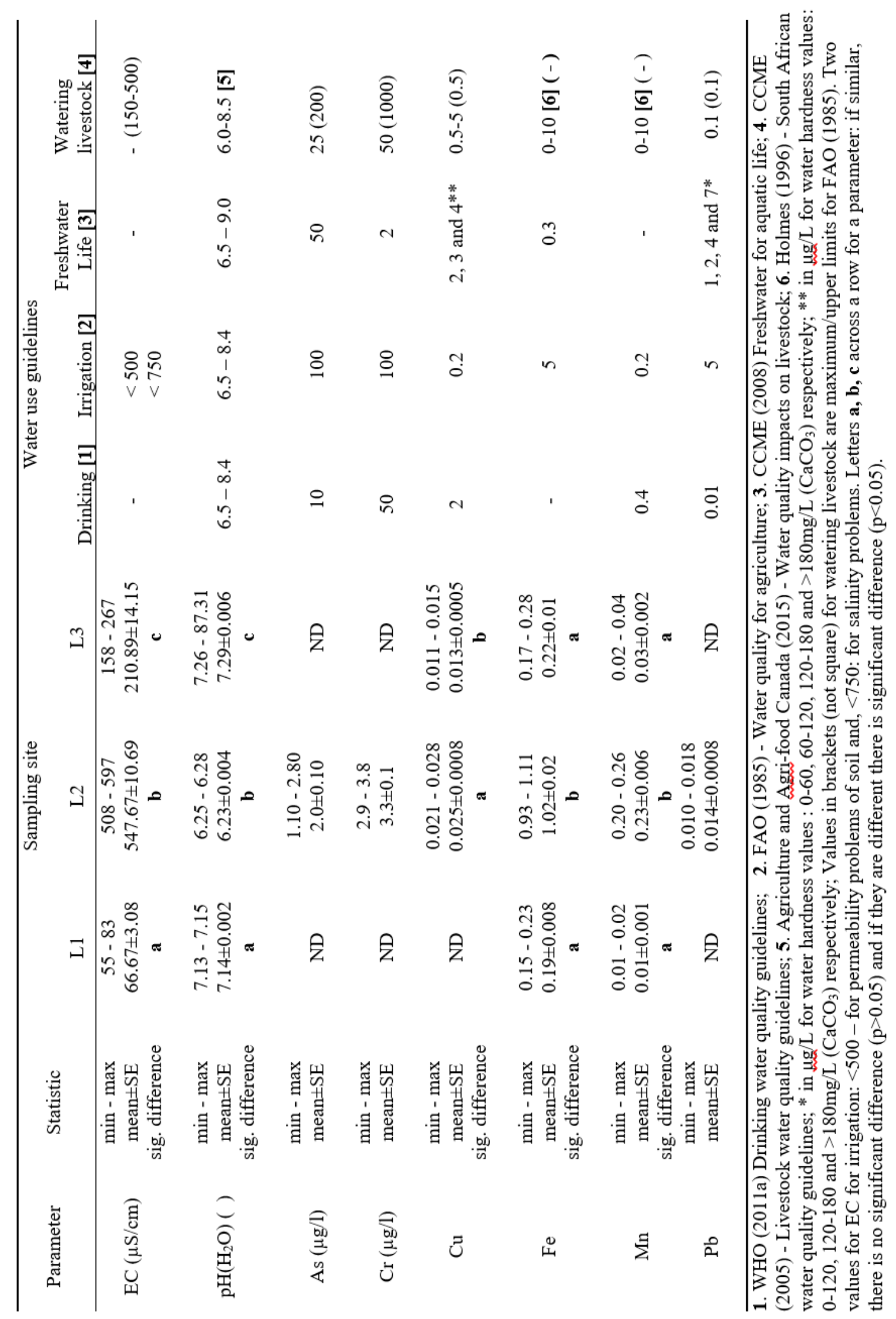


Artwell Kanda et al.

Tab. 3 Physicochemical parameters of sediment sampled from three pools of water along Mushayanyama Stream from September-November, 2015. Values are reported as means of replicate $(\mathrm{n}=9)$ measurements (mean $\pm \mathrm{SE}$ ). Units are $\mathrm{mg} / \mathrm{kg}$ for heavy metals unless specified.

\begin{tabular}{|c|c|c|c|c|c|c|}
\hline \multirow{3}{*}{ Parameter } & \multirow{3}{*}{ Statistic } & \multirow{3}{*}{ L1 } & \multirow{3}{*}{$\mathrm{L} 2$} & \multirow{3}{*}{ L3 } & \multirow{2}{*}{\multicolumn{2}{|c|}{$\begin{array}{c}\text { Sediment Quality } \\
\text { Guidelines* }\end{array}$}} \\
\hline & & & & & & \\
\hline & & & & & TEL & PEL \\
\hline & $\min -\max$ & & $0.011-0.017$ & & & \\
\hline \multirow[t]{2}{*}{ As } & mean $\pm \mathrm{SE}$ & ND & $0.014 \pm 0.009$ & ND & 5.9 & 17.0 \\
\hline & $\min -\max$ & & $0.020-0.029$ & $0.013-0.017$ & & \\
\hline \multirow[t]{3}{*}{$\mathrm{Cr}$} & mean $\pm \mathrm{SE}$ & ND & $0.025 \pm 0.0001$ & $0.015 \pm 0.0004$ & 37.3 & 90.0 \\
\hline & sig. difference & & $\mathbf{a}$ & b & & \\
\hline & $\min -\max$ & $0.03-0.05$ & $0.12-0.15$ & $0.05-0.08$ & & \\
\hline \multirow[t]{3}{*}{$\mathrm{Cu}$} & mean $\pm \mathrm{SE}$ & $0.04 \pm 0.002$ & $0.14 \pm 0.004$ & $0.07 \pm 0.003$ & 35.7 & 197.0 \\
\hline & sig. difference & $\mathbf{a}$ & b & $\mathbf{a}$ & & \\
\hline & $\min -\max$ & & $0.032-0.041$ & $0.010-0.020$ & & \\
\hline \multirow[t]{3}{*}{$\mathrm{Pb}$} & mean \pm SE sig. & ND & $0.04 \pm 0.001$ & $0.013 \pm 0.002$ & 35.0 & 91.3 \\
\hline & difference & & $\mathbf{a}$ & b & & \\
\hline & $\min -\max$ & $1.02-1.18$ & $3.29-4.04$ & $1.47-1.61$ & & \\
\hline \multirow[t]{3}{*}{$\mathrm{Fe}$} & mean $\pm \mathrm{SE}$ & $1.10 \pm 0.02$ & $3.69 \pm 0.08$ & $1.54 \pm 0.02$ & - & - \\
\hline & sig. difference & $\mathbf{a}$ & $\mathbf{b}$ & c & & \\
\hline & $\min -\max$ & $0.31-0.39$ & $1.62-1.85$ & $0.51-0.65$ & & \\
\hline \multirow[t]{3}{*}{ Mn } & mean $\pm \mathrm{SE}$ & $0.35 \pm 0.009$ & $1.75 \pm 0.002$ & $0.57 \pm 0.02$ & - & - \\
\hline & sig. difference & $\mathbf{a}$ & $\mathbf{b}$ & c & & \\
\hline & $\min -\max$ & $0.12-0.17$ & $1.27-1.68$ & $0.61-0.80$ & & \\
\hline \multirow[t]{3}{*}{ OM (\%) } & mean $\pm \mathrm{SE}$ & $0.14 \pm 0.006$ & $1.47 \pm 0.05$ & $0.69 \pm 0.02$ & - & - \\
\hline & sig. difference & $\mathbf{a}$ & $\mathbf{b}$ & c & & \\
\hline & $\min -\max$ & $7.12-8.12$ & $5.10-6.22$ & $6.98-8.00$ & & \\
\hline \multirow[t]{3}{*}{$\mathrm{pH}\left(\mathrm{H}_{2} \mathrm{O}\right)($ ) } & mean $\pm \mathrm{SE}$ & $7.12 \pm 0.12$ & $6.23 \pm 0.13$ & $7.27 \pm 0.12$ & - & - \\
\hline & sig. difference & $\mathbf{a}$ & b & c & & \\
\hline & $\min -\max$ & $154-182$ & $1853-1960$ & $412-494$ & & \\
\hline \multirow[t]{2}{*}{$\mathrm{EC}(\mu \mathrm{S} / \mathrm{cm})$} & mean $\pm \mathrm{SE}$ & $166.00 \pm 3.41$ & $1909.11 \pm 12.06$ & $445.44 \pm 9.70$ & - & - \\
\hline & sig. difference & $\mathbf{a}$ & $\mathbf{b}$ & c & & \\
\hline
\end{tabular}

* CCME (2001) 
Tab. 5 Results of other similar studies on heavy metal concentrations in water and sediments of streams and rivers.

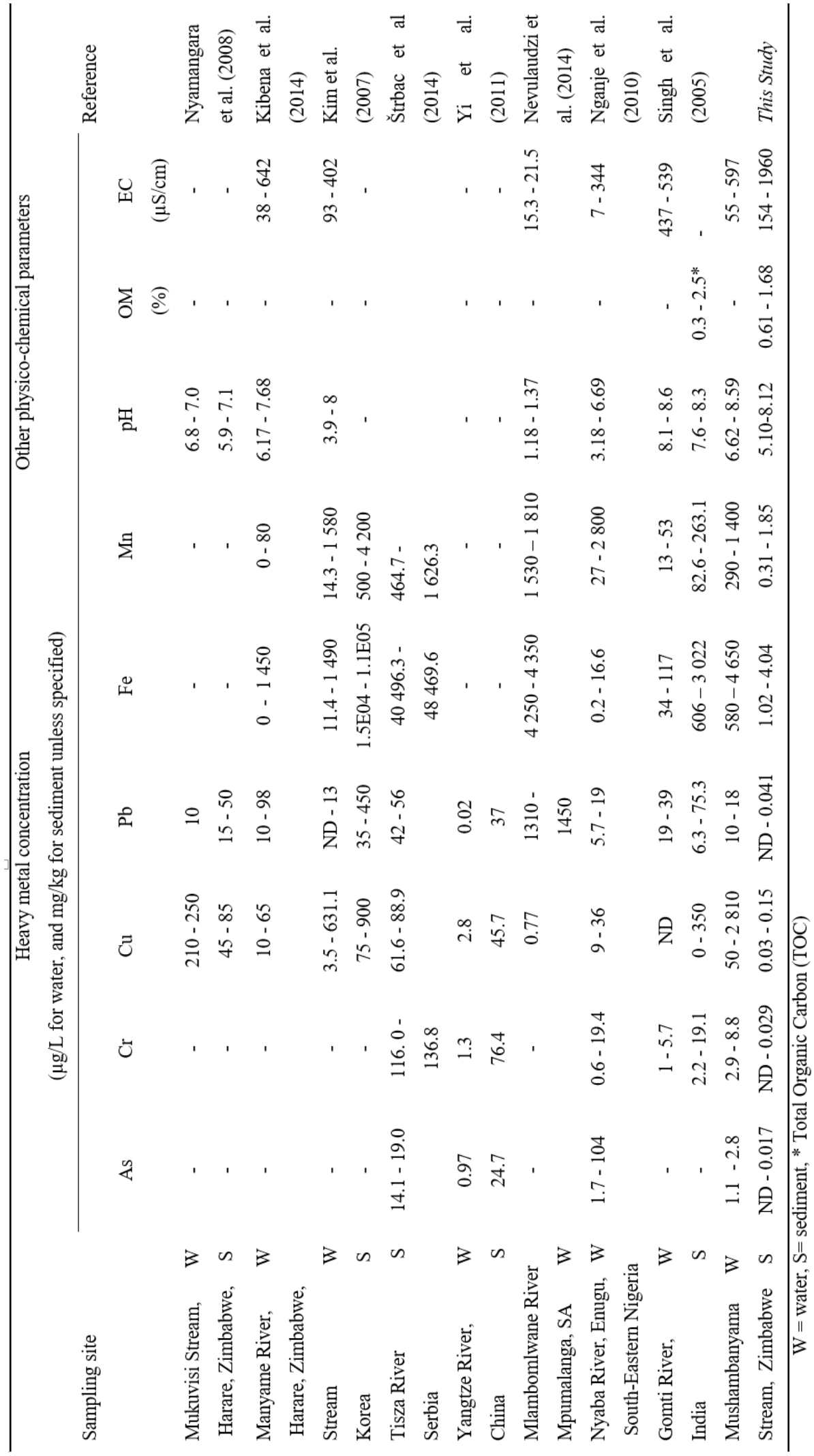


Tab. 6 Pearson correlation coefficients for water and sediment quality characteristics.

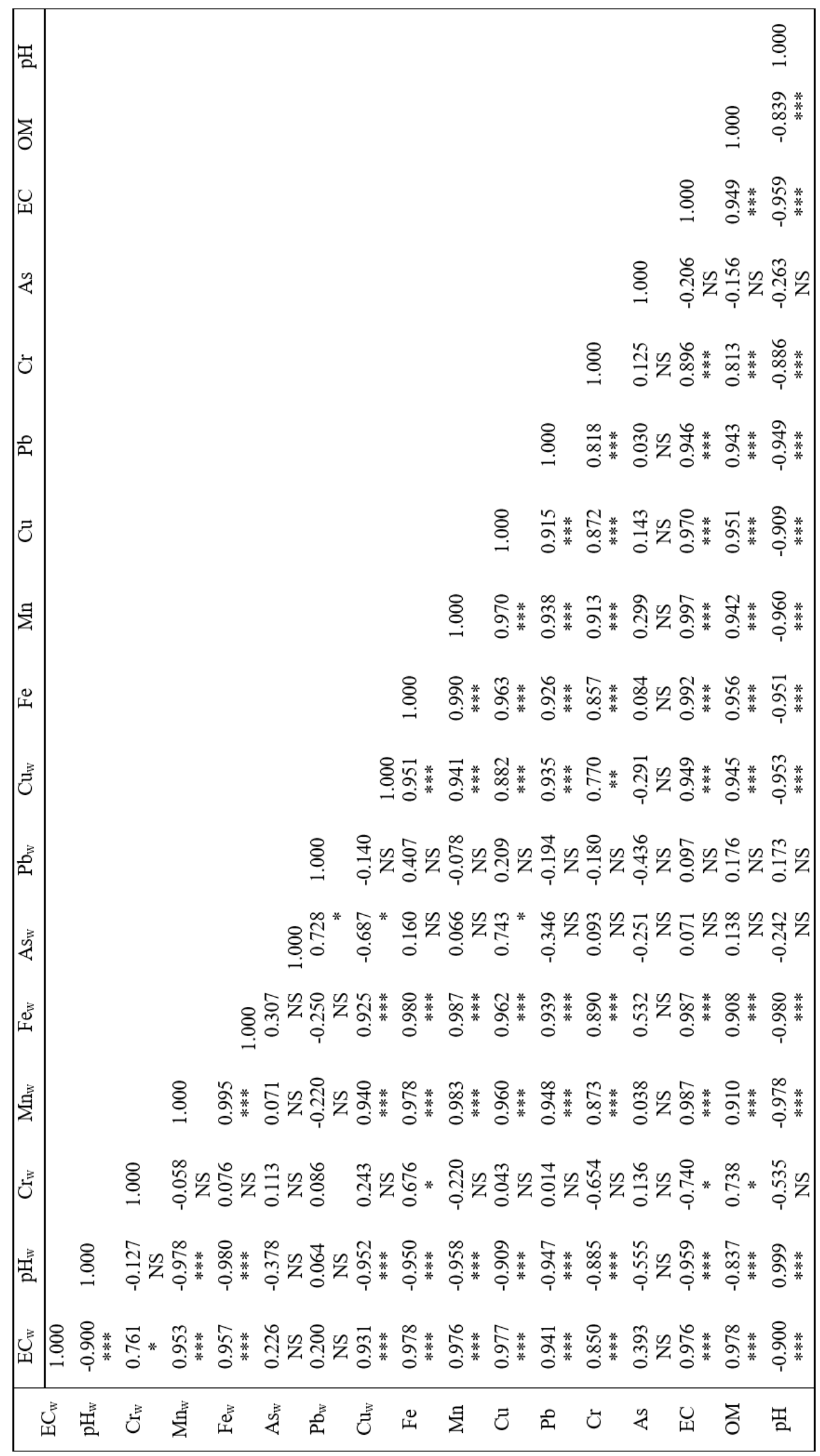




\section{Discussion}

\subsection{Heavy metal concentration in water and potential water uses}

Salinisation, acidification and metal loading observed at L2 (Tab. 2) could have come from the active mining tailings dam drainage. Chapman and Kimstach (1996) reported that these changes in river water could arise from the release of acidic mining wastewater. The export of heavy metals from mining tailings dams into the aquatic environment has been reported elsewhere (Kovacs et al. 2012; Modoi et al. 2014). The presence of heavy metals at L2 but not at L1 may suggest that an external source introduced them. The source of heavy metals could be the tailings dam since there were no inflows from surface runoff and there were turbulent flows within pools of water. Turbulent flows can introduce heavy metals into the water column (Eggleton and Thomas 2004). The absence of heavy metals in detectable quantities downstream (L3) after they were recorded at L2 may suggest self-purification through dilution by the stream. In natural waters $\mathrm{As}, \mathrm{Cr}$ and $\mathrm{Pb}$ are found in very small quantities of $<1$ $2,<2$ and $<5 \mu \mathrm{g} / \mathrm{L}$ respectively (WHO 2008). The concentration of $\mathrm{As}, \mathrm{Cr}, \mathrm{Cu}, \mathrm{Pb}$ and the $\mathrm{pH}$ for the three pools of water (L1, L2 and L3) along Mushambanyama Stream dictate water use options. The EC of water which put a restriction on water from $\mathrm{L} 2$ for irrigation plays an important role in the salinity of soil (FAO 1985). In natural waters at $\mathrm{pH}$ 6-9 Fe and Mn rarely occur at concentrations above $1 \mathrm{mg} / \mathrm{l}$ (Ongley 1996).

\subsection{Characteristics of sediment and sediment quality guidelines}

The higher concentrations of heavy metals in sediment at L2 than at L1 and L3 $(\mathrm{p}<0.05)$ suggest enrichment due to an external source. Metals showed strong significant correlation with $\mathrm{pH}$ and organic matter content. Sediment pH influences the mobilisation of heavy metals in sediments (Calmano and Forstner 1993).

Low $\mathrm{pH}$ releases more metal ions into solution. Organic matter form complexes with heavy metals limiting their bioavailability for plant and animal uptake (Hong et al. 2012). In their study, Idriss and Ahmad (2012) observed that the organic fraction had the second highest content of metal after the residual fraction. They explained the correlations between (1) organic matter and metals and (2) $\mathrm{pH}$ and metals, with respect to metal solubility, ultimately their availability. Huong et al. (2012) also observed correlations between organic matter and heavy metal concentrations in sediments. The water/sediment correlation for heavy metals $\mathrm{Cu}, \mathrm{Fe}$ and $\mathrm{Mn}$ were strong and significant. This could be due to the metal equilibrium which exists between the water column and the sediment (Eggleton and Thomas 2004).

According to CCME (2001) measured concentrations of sediment quality are compared to sediment quality Guideline values (SQGVs) and interpreted as concentrations: $S \mathrm{SQGV}$ : rare pollution, no ecological effects between SQGV and the probable effect level (PEL): moderate pollution with occasional negative ecological risks; >PEL: serious pollution with pronounced negative ecological effects. The concentrations of $\mathrm{As}, \mathrm{Cr}, \mathrm{Cu}$ and $\mathrm{Pb}$ in sediments from Mushambanyama Stream were below their respective interim sediment quality guidelines (ISQGs) $\mathrm{p}<0.05$ ). The four studied heavy metals therefore represent concentrations where adverse biological effects could rarely occur.

\subsection{Sediment quality using indices}

The contamination factors for $\mathrm{As}, \mathrm{Cr}, \mathrm{Cu}, \mathrm{Fe}, \mathrm{Mn}$ and $\mathrm{Pb}$ were all below unity suggesting no contamination of sediments from the pools of water. The PLI was also below unity implying no pollution of the pools of water (Tomlison et al. 1980). Computed I-geo values put all sediments in class 0 suggesting no contamination (Tab. 1). Pollution indices were in agreement with the sediment quality 
Artwell Kanda et al.

data in predicting no contamination for the pools of water with $\mathrm{As}, \mathrm{Cr}, \mathrm{Cu}, \mathrm{Fe}, \mathrm{Mn}$ and $\mathrm{Pb}$. These data were also in agreement with ecological pollution risk indices which showed low ecological risk for the three pools of water along Mushambanyama Stream. Similarities and differences in the parameters studied for Mushambanyama Stream with other studies (Tab. 5) may be due to both in-stream and watershed processes, hydrogeology, climate and anthropogenic activities.

\section{Conclusions}

This study showed that the degree of impairment of water quality with heavy metals dictates the potential uses of water. The concentrations of $\mathrm{Cr}, \mathrm{Cu}, \mathrm{Fe}$ and $\mathrm{Pb}$ restricted water use at a pool directly receiving mining tailings discharge for aquatic life. Using the upstream-downstream approach we showed that natural sources of pollutants (at L1) and tailings dam discharges (at L2) enriched sediments from pools of water with heavy metals although to levels lower than the sediment quality guidelines. Pollution indices, SQGs and potential ecological risk indices showed that the three pools of water along Mushambanyama Stream were not polluted and posed no potential ecological risk. The continuous monitoring of the quality of river water and sediments is critical for both ecosystem and human health as it reveals the potential health risks associated with anthropogenic pollution which can be identified and remediated.

\section{References}

Agriculture and Agri-food Canada (2015) Water quality impacts on livestock. Online: www.agri.gc.ca/eng/science-and-innovation/agricultural-practices/water/livestock-watering/waterquality-impacts-onlivestock/?id=1370621201553 (Cited 2016 July 19).

Calmano W, Hong J, Forstner U (1993) Binding and mobilization of heavy metals in contaminated sediments affected by $\mathrm{pH}$ and redox potential. Water Science and Technology 28: 223-235.

CCME (2001) Canadian sediment quality guidelines for the protection of aquatic life: Summary tables. CCME, Winnipeg.

CCME (2005) Canadian water quality guidelines for the protection of agricultural water uses. CCME, Winnipeg.

CCME (2008) Canadian water quality guidelines. CCME, Ontario.

Chapman D, Kimstach V (1996) Selection of water quality variables. In: Chapman D (Ed.) Water quality assessments- A guide to use of biota, sediments and water in environmental Monitoring. E \& EN Spon, London pp. 74-133.

Ciszewski D, Aleksander-Kwaterczak U, Pociecha A, Szarek-Gwiazda E, Waloszek A, Wilk-Woźniak E (2013) Small effects of a large sediment contamination with heavy metals on aquatic organisms in the vicinity of an abandoned lead and zinc mine. Environmental Monitoring and Assessment 185: 9825-9842. DOI: 10.1007/s10661-013-3295-z

Divrikli U, Kartal AA, Soylak M, Elci L (2007) Preconcentration of $\mathrm{Pb}(\mathrm{II}), \mathrm{Cr}(\mathrm{III}), \mathrm{Cu}(\mathrm{II}), \mathrm{Ni}(\mathrm{II})$ and $\mathrm{Cd}(\mathrm{II})$ ions in environmental samples by membrane filtration prior to their flame atomic absorption spectrometric determinations. Journal of Hazardous Materials 145:459-464. DOI: 10.1016/j.jhazmat.2006.11.040

Eggleton J, Thomas KV (2004) A review of factors affecting the release and bioavailability contaminants during sediment disturbance events. Environment International 30: 973-980. DOI:10.1016/j.envint.2004.03.001

FAO (1985) Water quality for agriculture, Irrigation and drainage paper No. 29, Rev. 1. FAO, Rome.

Forstner U (1989) Lecture Notes in Earth Sciences: Contaminated sediments, Chapter 6: Environmental Impact, 6.2, Pollution Indices. Springer-Verlag, Berlin.

Forstner U, Wittmann GTW (1981) Metal pollution of the aquatic environment. Springer-Verlag, Berlin.

Hakanson L (1980) An ecological risk index for aquatic pollution control - a sedimentological approach. Water Research 14: 975-1001. DOI:10.1016/0043-1354(80)90143-8 
Artwell Kanda et al.

Hammer Ø, Harper DAT, Ryan PD (2001) PAST: Paleontological statistics software package for education and data analysis. Palaeontologia Electronica 4: 9.

Holmes S, (Ed.) (1996) South African Water quality guidelines: Agricultural use - Livestock Watering. Department of Water Affairs and Forestry, Pretoria, South Africa.

Huong NTL, Ohtsubo M, Higashi T and Kanayama M (2012) Heavy metal concentration in sediments of the Nhue River and its water-irrigated farmland soil in the suburb of Hanoi, Vietnam. Soil and Sediment Contamination 21:364-381.

Idriss AA and Ahmad AK (2012) Heavy metal concentrations $(\mathrm{Cu}, \mathrm{Cd}$ and $\mathrm{Pb})$ in sediments in the Juru River, Penang, Malaysia. Journal of Biological Sciences 12:376-384.

Jaishankar M, Tseten T, Anbalagan N, Mathew BB, Beeregowda KN (2014) Toxicity mechanism and healthy effects of some heavy metals. Interdisciplinary Toxicology 7: 60-72. DOI: 10.2478/intox2014-009

Jonnalagadda SB, Mhere G (2001) Water quality of the Odzi River in the eastern highlands of

Zimbabwe. Water Research 35: 2371-2376.

Kibena J, Nhapi I, Gumindoga W (2014) Assessing the relationship between water quality parameters and changes in land-use patterns in the upper Manyame River, Zimbabwe. Physics and Chemistry of the Earth 67-69: 153-163.

Kim JG, Ko K-S, Kim TH, Lee GH, Song Y, Chon C-M and Lee J-S (2007) Effect of mining and geology on the chemistry of stream and sediment in a small watershed. Geosciences Journal 11:175183.

Kovacs E, Tamas J, Franciskovic-Bilinski S, Omanovic D, Bilinski H, Pizeta I (2012) Geochemical study of surface water and sediment at the abandoned $\mathrm{Pb}-\mathrm{Zn}$ mining site at Gyongyosoroszi, Hungary. Fresenius Environmental Bulletin 21: 1212-1218.

Liu WH, Zhao JZ, Ouyang ZY, Liu GH (2005) Impacts of sewage irrigation on heavy metal distribution and contamination in Beijing, China. Environment International 31: 805-812. DOI:10.1016/j.envnt.2005.05.042

Maher W, Batley GE, Lawrence I (2011) Assessing the health of sediment ecosystems: use of chemical measurements. Freshwater Biology 41: 361-372.

Majnoni F, Alipour H, Hassanpour M, Banagar G, Ajorlo M (2015) Assessment of Cd, Cr and Pb pollution in sediment and water of Gheshlagh River, Iran, in September, 2013. Iranian Journal of Toxicity 9: 1264-1270.

Modoi OC, Roba C, Torok Z, Ozunu A (2014) Environmental risks due to heavy metal pollution of water resulted from mining wastes in NW Romania. Environmental Engineering and Management Journal 13, 2325-2336.

Mohiuddin KM, Ogawa Y, Zakir HM, Otomo K, Shikazono N (2011) Heavy metals contamination in water and sediments of an urban river in a developing country. International Journal of Environmental Science and Technology 8: 723-736.

Mulller G (1969) Index of geoaccumulation in sediments of the Rhine River. Geology Journal

2:109-118.

Nevhulaudzi T, Kambewa C, Kanu SA (2014) Water quality around the Sheba gold mine: a case study of the Mlambomlwane River in Sheba, Mpumalanga Province, South Africa. Scholarly Journal of Research and Essay 3: 112-119.

Nganje TN, Adamu CI, Ntekim EEU, Ugbaja A, Neji P, Nfor EW (2010) Influence of mine drainage on water quality along River Nyaba in Enugu South-Eastern Nigeria. African Journal of Environmental Science and Technology 4: 132-144. DOI: 10.5897/AJEST09.146

Nhapi I, Tirivarombo S (2004) Sewage discharges and nutrient levels in Marimba River, Zimbabwe. Water South Africa 30: 107-113.

Nyamadzawo G, Mapanda F, Nyamugafata P, Nyamangara J, Wuta M (2007) Short-term impacts of sulphate mine dump rehabilitation on below ground water and surface water of Yellow Jacket River, Mazowe, Zimbabwe. Physics and Chemistry of the Earth 32:1376-1383. DOI: 10.1016/j.pce.2007.07.043

Nyamangara J, Bangira C, Taruvinga T, Masona C, Nyemba A, Ndlovu D (2008) Effects of sewage and industrial effluent on concentration of $\mathrm{Zn}, \mathrm{Cu}, \mathrm{Pb}$ and $\mathrm{Cd}$ in water and sediments along Waterfalls Stream and lower Mukuvisi River in Harare, Zimbabwe. Physics and Chemistry of the Earth 33: 703-713. DOI: 10.1016/j.pce.2008.06.053 
Artwell Kanda et al.

Ongley E (1996) Sediment measurements. In: Bartram J, Balance R (Eds.) Water quality monitoring A practical guide to the design and implementation of freshwater quality studies and monitoring programmes. UNEP/WHO, Geneva, pp. 301-315.

Shoko DSM, Tobani NA (2002) Detailed prospectus of the Shamva gold mine new slimes dam project. University of Zimbabwe Publications, Harare.

Singh KP, Mohan D, Singh VK, Malik A (2005) Studies on distribution and fractionation of heavy metals in Gomti River sediments - a tributary of the Ganges, India. Journal of Hydrology 312: 1427. DOI: $10.1016 / \mathrm{j} / \mathrm{jhydrol} .2005 .01 .021$

Soliman NF, Nasr SM, OKbah MA (2015) Potential ecological risk of heavy metals in sediments from the Mediterranean Coast, Egypt. Journal of Environmental Health Science and Engineering, 13:70. DOI:10.1186/540201-015-0223-X

Štrbac S, Šajnović A, Kašanin GM, Vasić N, Dojčinović B, Simonović P and Jovančićević, B (2014) Metals in sediment and Phragmites australis (common reed) from Tisza River, Serbia. Applied Ecology and Environmental Research 12:105-122.

Tomlison Dl, Wilson JG, Harris C, Jeffrey DW (1980) Problems in the assessment of heavy metal levels in estuaries and the formation of a pollution index. Helgolander Meerresunter 33, 556-572.

Turekain KK, Wedpohl KH (1961) Distribution of the elements in some major units of the Earth's crust. American Geology Society 72: 175-182.

WHO (2011a) Guidelines for drinking-water quality. World Health Organisation, Geneva.

WHO (2011b) Adverse health effects of heavy metals in children, Children's health and the Environment, WHO Training package for the health sector. WHO, Geneva.

WHO (2008) Guidelines for drinking water. WHO, Geneva.

Yi Y, Yang Z, Zhang S (2011) Ecological risk assessment of heavy metals in sediment and human health risk assessment of heavy metals in fishes in the middle and lower reaches of the Yangtze River Basin. Environmental Pollution 159: 2575-2585. 